\title{
Dismal Transition, Retention and Performance of the Girl-Child: What are the Explanatory Variables in Rhamu Town, Mandera County, Kenya?
}

\author{
Aftin K. Dube ${ }^{1}$ And John Aluko Orodho ${ }^{2 *}$ \\ ${ }^{I}$ Department of Educational Management, Policy and Curriculum Studies, Kenyatta University, Kenya \\ ${ }^{2}$ Department of Educational Management, Policy and Curriculum Studies, School of Education, Kenyatta \\ University, Kenya
}

\begin{abstract}
This study sought to examine the dismal transition, retention and performance the girl-child in secondary schools in Rhamu Town in Mandera County, Kenya. The major research question is; what are the explanatory variables for this dismal participation? The study was premised on the Classical Liberal Theory of Opportunity and Darwinism whose major tenet is that each person is born with a given amount of capacity, which to a large extent is inherited and cannot be substantially changed. Mixed methods employing descriptive and multi-case studies research designs were used to conduct the study in Rhamu Town. A combination of purposive and stratified random sampling techniques were used to draw 18 teachers, 120 students and 54 parents yielding a total sample size of 192 subjects to participate in the study. Questionnaires were used to collect data from teachers and students, while interviews and focus group discussions were used to collect information from parents. Quantitative data from questionnaires were analyzed with the assistance of the statistical package for social sciences (SPSS) computer programme Version 20 to generate descriptive statistics such as means and charts. Information from interviews and FGDs was transcribed and thematically analyzed and reported in narrative and direct quotes. It was established that there was high wastage of girls in the schools system because after initial high enrolment of the girls in lower classes of pre-school and primary schools, most of the girls dropped out in upper classes of primary schools particularly between class 5 and 8 . The few who proceeded to secondary schools dropped out before completing, thereby portraying very dismal retention and progression profile. The performance of the females compared to their male counterparts was equally poor. The major causes for this state of affairs were: inability of parents to cater for latent school levies due to poverty at the household level, retrogressive socio-cultural practices and low premium attached to the education of the girl-child, early pregnancies and marriages, and inability of the Government through the Ministry of Education to sensitize parents on the value of education as well as enforce punitive aspects of the Basic Education 2013 on parents who fail to take their children of any gender to school. It was recommended that the Government of Kenya should enforce the Children's Act that outlaws early forced marriage and punish parents who do not take children of school going age to schools in Mandera County, Kenya( 398 words)
\end{abstract}

Keywords: Access, Attitude, Coping mechanism, gender disparities, retrogressive cultures, retention and progression, Rhamu Town, Mandera District, Kenya.

\section{Background Information}

\section{Introduction}

A large body of research on access to school and progression to upper classes around most African countries consistently confirm that girls considerably outnumbered boys in Early Childhood Education and lower primary with the reverse being noticed in transition to upper primary and secondary school levels where boys overtake the girls ( Mwaniki \& Orodho, 2014; Orodho, 2013). With regards to participation, there is growing concerns that girls, especially those from among the Arid and Semi-Arid (ASAL) pastoralist communities have continuously under-performed in national examinations in upper classes compared to boys ( Orodho,2014). The pattern of results have generally led to the assumption that the observed girls' underperformance is due to their underrepresentation in those class levels, especially in secondary schools, the . As such policies that attempted to address the problem of female under representation and poor performance in such areas have been skewed in favour of the females (Orodho, 2014). The bulk of research studies have focused on the causes of female underrepresentation not only in access and performance in education but also in wage employment (Njeru \& Orodho, 2003).

As a consequence of the foregoing, identifying factors that influence students' learning and thus achievement continues to be an important objective of educators at all levels (Njeru \& Orodho, 2003). Various factors affect student achievement at secondary education level like personal confidence and a feeling of 
competence in learning; hopeful but realistic projection into the future occupational roles and social roles; emotional stability; temperamental tendency towards introversion; relative independence from teachers and a tacit acceptance of the of the curricular and work demands arising within the structure of tuition (Mwaniki \& Orodho, 2014). Self-efficacy has been identified as a positive predictor of academic performance.

Achievement is affected by students' personal characteristics, attitudes, activities and most of all students' interest and engagement. Students with low academic self-esteem and the students that are not interested and actively engaged are at a significantly higher risk of low achievement (Mwaniki \& Orodho, 2014; Orodho, 2014). Students' attitude towards a particular subject has a positive relationship with achievement (Bos \& Kuiper, 1999). Cognitive aspects, motivational factors, teaching methodology and classroom-contextual factors exercise a significant influence. Cognitive factors including cognitive capabilities, previous knowledge, and, to some extent, subject-specific self-concept are important for achievement (Von et. al, 1998).

Along with these factors pertaining to the students' personalities, a recent study by Orodho (2014) has demonstrated that family background is also very important. Researches from other regions of the world are also in agreement with the Orodho (2014) finding and indicate that students from lower socio-economic background in terms of parents' occupational status faced a higher risk of low achievement. Home educational background and parents' educational attainment greatly influences the quality of education for their children. Student achievement was found to be directly proportional to the education of their parents ( Orodho,2013 ). The cultural factors of the home in the Kenyan context were other family characteristic that proved significant in predicting low achievement (Njeru \& Orodho, 2003).

Notwithstanding the foregoing research efforts, an emerging scenario in Kenya seems to indicate that the males are slowly being overtaken by their female counterparts in access and participation in education in some counties such as Subukia District in Nakuru County in the country (Mwaniki \& Orodho, 2014). The case of Subukia District in Nakuru County indicates that the performance of males in KCSE has been declining compared to their female counterparts over time. According to the Ministry of Education (2012), the district's mean score was B in 2009, B- in 2010 and C+ in 2011. Though boys were reported to have more quality grades than girls ( $\mathrm{B}+$ and above), the average grade for boys was generally lower than for girls. While $35 \%$ of girls scored $\mathrm{C}+$ and above, $23 \%$ of boys scored similar grades. These reversing scenarios seem to complicate matters as we cannot conclude that girls are a more disadvantaged gender in access and performance in education in Kenya( Republic of Kenya/UNESCO,2012). It is against this backdrop that the researchers undertook to diagnose this problem of girls' dismal access, retention, transition and performance in national examinations in Rhamu Town, Mandera County, with a view to prescribe some plausible intervention strategies.

\section{Review of related Literature}

In Kenya, despite the significant progress in achievement of universal basic education at the national level after the introduction of free primary education (FPE) and free day secondary education (FDSE), there are severe gender and regional disparities in educational participation at all levels ( Orodho,2014; Republic of Kenya/UNESCO,2012). For instance, enrollment in schools in Mandera is low and portrays poor gender parity. Yet the future of many countries depends on how well their citizens are educated, the type of education offered and how well it is developed (Republic of Kenya, 1997). At independence, Kenya had three major problems to solve; poverty, ignorance and disease. Kenya decided to lay more emphasis on education as the key to economic, social and political development (Republic of Kenya, 1964). In spite of the fact that improving and widening access to education has been major goal of the Kenya government, the history of education opportunity especially in pastoral areas still holds cultural inequality and disparity between boys and girls (UNICEF, 2003).

The right to education has been reaffirmed internationally (UNICEF, 2001; United Nations ,2013). Article 28 of the United Nations Convention on the rights of the child states that every child has a right to education no matter what his or her circumstances and the Government of Kenya has stated its commitment to making this a reality (Republic of Kenya, 2005). Indeed the Government of Kenya seeks to ensure equity in terms of equal access to education (Republic of Kenya, 2005). This commitment to achieving equity is of utmost importance since equity in education is a fundamental principle of the EFA Agenda. According to UNESCO (2008), equity in education should ensure provision of appropriate, relevant and viable learning opportunities to all children without distinction of location.

Studies on access and retention in primary and lower secondary education in Ghana show that although the FCUBE made an overall enrolments increase, children from poor households continue to be underrepresented in enrolments (Rolleston, 2009). Rolleston (2009) made it explicit that not only indirect costs hinder access of the poor but also opportunity costs substantially affect the chances of poor children to enroll in and complete basic education. A study of access patterns in Malawi also concludes that access to education in the country continues to reflect household wealth (Chimombo, 2009). Thus, despite direct fees being abolished, these studies clarify that the abolition of fees has not been enough to ensure access to education for the poor. 
For instance, a study by Mensch and Lloyd (1998) on gender difference in primary school experiences in Kenya shows that some primary school teachers limit girls' incentives to continue further education and to delay marriage and child bearing. Their study also found for example that, the awarding of academic prizes appears to be biased in favour of boys that boys outperformed girls in the primary leaving examination and that gender gaps in achievement were greater in low-performing schools. In fact, teachers' low expectations towards girls' academic performances can reduce girls' motivations and discourage them from continuing further education (UNESCO, 2008). Gender-stereotyped households and occupational roles presented in textbooks and curriculum also negatively affect girls' aspirations to further education.

Another major threat affecting girls is unique climatic condition of the Arid and semi-Arid lands which makes provision of education a challenge. These areas experience extremes in climatic conditions which are at times characterized by frequent droughts. The terrain is harsh as much of it is dry with average rainfall of only $250 \mathrm{~mm}$. (Republic of Kenya, 1976). In arid and semi-arid areas such as NEP, the level of poverty and economic under-development may be higher than in other parts of the country with kinder weather patterns. This is because the mainstay of the country is agriculture and therefore weather patterns play an important role in the economy.

The economic activity in the region also affects education. The major economic activity carried out is pastoralist in nature, with many of the communities being nomadic. Worldwide, nomads are among groups that are considered neglected, (UNESCO, 2008). Mandera District in Kenya is considered to be one of the homes of the poorest of the poor with over $60 \%$ of the population living below the poverty line (Republic of Kenya, 2005). This is the reality for the children in North Eastern province areas. All these factors point to the variety of handicaps the girl child faces. This situation is summed up well by Poole (1981) whose studies in Australia observed that multiple factors produce and reproduce disadvantage. Students from North eastern region are disadvantaged, this being a condition that is experienced by minority groups.

Access to government secondary school system in Kenya is meritocratic; selection is based purely on performance in the primary leaving examination and admission to public secondary schools is highly competitive (Njeru \& Orodho,2003). Since the quota system of selection is used with a view of promoting national integration and unity among the youth (Ministry of Education, 1996), the national secondary schools are a meeting point for students from varied social, economic and cultural backgrounds. Lockheed and Verspoor, (1991) state that certain groups of children are educationally disadvantaged in virtually all societies; this is reflected in their educational attainment.

Given that those children who reach the last grade of primary school are more likely to be from betteroff households, children from poorer households are less likely to be able to access secondary education. The transition rate in 1967/68 was 24.1percent Ministry of Education and Republic of Kenya (1972a, 2006a) Economic Survey. This means that less than one in four children who enrolled in the last grade of primary school in 1967 accessed secondary education in 1968. Since then, while the transition rate fluctuated until recently, the overall transition rate has improved. In 2006/07, it is estimated that the transition rate reached 60 percent. This suggests that six in every 10 children enrolled in the last grade of primary school in 2006, became enrolled in secondary school in 2007. Available data on the transition to secondary school by gender show that more boys than girls have enrolled in secondary school in the past decade. The Gender Parity Index (GPI)16 indicates that there are 89 girls for every 100 boys in form 1 in 2005 , and this figure has not significantly changed since 1995. This suggests that there are persistent gender disparities in access to secondary education, despite rapid increases in form one enrolments in recent years. There are still concerns about who accesses secondary school in Kenya, despite increases in overall numbers.

In 2005 , it was estimated that there were 4,169 secondary schools in Kenya, of which $83 \%$ were public and 17 percent were private. Data from the Ministry of Education show that the number of secondary enrolments in 2005 was approximately 928,000 , of whom 8.9 percent were in private secondary schools. This suggests that the majority of secondary school students in Kenya attend government schools. Though there are several reasons for low transition rates, insufficient school supply and high costs of fees are two important causes (Ministry of Education, 2004, 2005). In general, the comparison of grade enrolments from the first grade of primary school to the first grade of secondary school shows a clear shift of enrolment patterns, where wealth becomes an increasing factor in access as children move through the grades. As primary and secondary enrolment figures show, the chances of a child getting into secondary school are determined by household wealth. This therefore raises concerns about whether enrolments in secondary school can be helped via bursaries and free secondary education for the poor. The Ministry of Education's documents ( Republic of Kenya, 2004, 2005) point out other reasons such as high level of poverty, extra levies for private tuition, unfriendly school environment, negative effects of HIV/AIDS pandemic and rising repetition rates.

To deal with the inability of poor and vulnerable households to pay secondary school fees, the Government of Kenya created a bursary scheme in 1994. The underlying rationale is that no child who qualifies academically for secondary education should be denied access to secondary education because of the inability to 
pay school fees. The objective therefore is to provide financial assistance to economically and socially needy students in all public secondary schools (Republic of Kenya, 2002c). In order to achieve a fair and equitable allocation of the bursary, the government set up the following formula when the scheme was established:

- $25 \%$ of all bursaries were to be allocated to arid and semi-arid land (ASAL) districts;

- $70 \%$ of all bursaries were to be allocated to schools in all districts (including ASAL);

- $5 \%$ of the bursaries were to be allocated to the national schools to cater for students who come from disadvantaged areas.

However, the Ministry of Education gradually deviated from the original formula in terms of the proportion of allocations, and gave two percent of the bursary allocation to needy students whose parents are among the staff of the Ministry of Education (Republic of Kenya, 2002c). Moreover, a government report by the controller and auditor found that as much as 14 percent of the bursary allocation was given to needy students of Ministry staff in 2001/02. The report underscores that "the above share out of bursary funds clearly contradicted the original cabinet policy decision on the issuances of Bursaries" (ibid, 2002c: 157). Furthermore, the report concludes that "the Ministry has not established a proper and reliable system for monitoring the disbursement of bursaries to ensure that the money reaches the intended beneficiaries" (ibid, 2002c: 157). Thus, it was not known whether the bursary reached the targeted students. This demonstrates concern for the effective and equitable distribution of the bursary scheme. Another study by Njeru and Orodho (2003) on the bursary scheme found that although there were students who benefited from bursaries, this had no significant impact on enrolment by the poor. They concluded that because the scheme targeted students already enrolled in secondary school, it missed students who had failed to raise the initial school fees, so the scheme ignored students who had not already been able to gain access, despite their academic eligibility. These reports raise critical questions about whether government bursaries reach intended beneficiaries and in so doing expand access for those who are excluded, or whether the government reinforces the exclusion of the poor by awarding bursaries to financially able groups whose children are already in secondary school. Since children from the bottom wealth quintiles have fewer chances to enroll in secondary school than children from the top wealth quintiles, it is important that government bursaries reach the poor.

Communities in arid and semi-arid lands have lagged behind in education, (Government of Kenya, 2003). Part of the reason for this situation was the historical background. Eshiwani (1993) traces the origin of inequality in education in Kenya to the colonial period. During the colonial period, the state concentrated its resources on European and some Asian children. Historically, Kenya's ASALs received low priority in allocation for development resources. This for a long time was justified on economic grounds that aimed to maximise productivity in areas with known and proven potential. Republic of Kenya (1976) points to the fact that there are imbalances of access to education between districts and divisions and between sexes existed because of historical, socio-economic, socio-cultural and environmental factors. The report pointed out that the imbalances were particularly serious among the nomadic communities. These areas were formerly demarcated as 'closed' districts of Eastern, North Eastern and Rift Valley provinces during the colonial period. Movement to and out of the districts was restricted. This meant that the ASAL regions were entirely neglected in the development of education. At independence the country had to deal with these disparities which various education commissions have sought to remove (Republic of Kenya, 1964, 1976, 1999). Despite the government's commitment to provide education for all, ASAL areas still remain disadvantaged.

Challenges in ASAL are not only limited to the physical and economic conditions. Njeru and Orodho (2003) further point out that some retrogressive, socio economic and cultural traditions, religious values and practices have greatly affected access and participation in secondary school education. A study by Saru (2006) revealed that some of the socio-cultural factors affecting performance in ASAL area: circumcision, early marriages, low opinion of women and a lack of priority in education. Several studies conducted in arid and semi-arid lands point to the fact that the boy child is favoured over the girl (Noor, 2003; Juma, 1994,). Many of these studies try to explain the factors affecting the girl-child education. In a study carried out by Noor (2003) on accessibility and retention of girls in secondary education in North Eastern Kenya, a variety of reasons are given that prevent girl education, pointing to the fact that girls are clearly disadvantaged.

Juma (1994) identified cultural practices such as nomadic pastrolism as a factor which influences girls' aspirations in school. In this practice families move far away from settlement areas where schools are located in search of water and pasture for their livestock. When this movement happens parents are forced to withdraw their children from schools. In her study, Noor (2003) found that girls are more affected than boys since girls cannot be entrusted with anybody and have to accompany their parents wherever they go.

Girls' education is also affected by their having to contribute to house hold chores. They are sometimes taken away from school to help in the home, nurse babies, clean the house, and fetch firewood and water, cook food and milk cows (Juma, 1994). Such household duties, long distances from school result in physical and mental exhaustion which makes learning boring and difficult. All this leaves the child overwhelmed both at 
school and at home. Accessibility to school is another problem that faces girls in ASAL areas. In her study, Noor (2003) notes that in Mandera district, the distance between home and school is a major problem to girls since many parents do not allow their daughters to walk alone. They are thus kept out of school unless there is somebody preferably an older brother to accompany her to school. This decision is bound to affect the girls' performance in school.

Proximity and access to secondary school is a pre-determining factor to enrolment and retention (Noor, 2003; Orodho, 2014). In ASAL areas, distance between school and homes is far and the educational delivery systems are often incompatible with the lifestyle of nomadic people (Noor, 2003, Khalif, 2008). Noor (2003) and Orodho (2014) further observe that distance between school and home affects girls more than it does boys because parents are afraid to let the girls walk alone unless she is accompanied by an older brother. Security in and out of school is of utmost concern for girls. Some of the girls who walk long distances to school end up being raped and sexually abused by older boys and male adults (Noor, 2003). Building boarding schools as a solution to curb the problem of distance between school and home has not tackled the problem. A study carried out by Orodho (2014) revealed that despite the presence of boarding schools in Garissa municipality, there was no single girl, despite the fact that boarding for girls would give the girls greater security. There was no girl boarder since a girl should not be left to stay away from her parents or adult relative. This decision is a further reflection of how cultural practices affect access to education in the ASAL areas. Although boarding schools solve the problem of distance, culture does not free the young girls to stay in boarding school, therefore the girls miss school.

Early marriages also affect access and retention in education in ASAL areas. Ombongi (2008) in his study carried out in Isiolo, one of the ASAL districts; found that early marriages influenced participation in education. Girls in standard 4 or between 12 and 14 years were withdrawn from school to be married off to wealthy men in the community in exchange for dowry. The study goes on to say that girls who remained in school were under constant pressure from their peers and community members including their own parents to drop out of school. Boys on the other hand are expected to marry and establish families almost immediately after circumcision. Upon circumcision the boys are given a herd of cattle so as to start accumulating wealth for the family they are about to establish. This practice has led to a low value being attached to education since in these communities economic empowerment supersedes academic achievement (Ombongi, 2008).

School related factors have also inhibited enrolment and participation in education in North Eastern Kenya (Orodho, 2014). A study carried out by Orodho (2014) reveals that school factors not only inhibit but also negatively affect children's performance. The study observes that poor school environment including rudimentary shelters, lack of desks, overcrowding, lack of water sanitation facilities and poor safety standards are factors blocking enrolment and successful completion of schooling. This particularly affects the girls. The North Eastern province suffers high teacher turn over owing to interplay of factors such as harsh climatic conditions, poor infrastructure, insecurity and lack of teacher housing. As a result, teachers from other parts of the country do not want to serve in the province. Since teachers find these areas difficult to survive in they look for transfers as quickly as possible leaving the area deprived of teaching force

\section{Statement of the Problem}

Despite the fact that a number of studies have been done on factors that prohibit the girl-child from access, performance and retention in secondary schools in North Eastern province, Orodho (2014), no specific study has investigated the continued inaccessibility and low retention among the girl child in secondary schools in Rhamu town, Mandera District in Kenya. It is against this backdrop that this study which attempts to delve deeper and explore this problem was conceived. The study attempted to address some factors that prohibit the girl-child from access, performance and retention in secondary schools from arid areas not fully covered in the studies discussed hitherto.

\section{Purpose and Objectives of the Study}

The purpose of this study was to find out the factors that prohibit girl-child from access, performance and retention in secondary school education in Mandera District in Kenya. The study was designed to achieve the following five objectives:

1. To examine the status of girls' secondary education in the district.

2. To determine the factors that affect enrolment, retention and performance in secondary schools among girls within Mandera District.

3. To assess the perception of the girl-child and the view of the community regarding educating girls.

4. To identify the key challenges that prevents girls from accessing secondary education despite free secondary education.

5. To identify suggestions for addressing the problem identified above. 
The researcher adopted the classical liberal theory of opportunity and social Darwinism. The theory asserts that each person is born with a given amount of capacity, which to a large extent is inherited and cannot be substantially changed. It also states that social mobility is promoted by equal opportunity of education. Natural statesmen were born equal and personal qualities should not jeopardize social equality as long as society rewards people according to their status (Rousseau, 1712-1778).

Thus education system should be designed so as to remove barriers of any nature be it economic, gender or geographic that prevents bright students from lower economic background from taking advantage of inborn talents, which accelerates them to a social promotion. The theory demands going through education at primary and secondary levels to which access would be determined on the basis of individual's merit and not social or geographical background.

Social Darwinism emphasizes that every citizen should be given, through education the social status which entitles him or her to inherit aptitude (Organization for economic co-operation development 1975). It can document who deserves the money because his/her achievements are determined by inherited capabilities and he/she will use them and not arbitrary conditions like economic status or geographic conditions.

The theory was found appropriate for the study because of equity consideration; it becomes practically impossible to ignore the fact that unequal participation in education will in the long run affect the status of the poor and the vulnerable groups like the girl- child from ASAL areas. For example, if the government fails to provide mitigating factors to arrest the issue of low enrolment in ASAL, areas then education for all will not be effectively realised.

\section{Research Methodology}

Descriptive survey design was adopted because it is ideal for gathering information regarding people's behaviour, feelings and opinions about educational issues (Orodho, 2009, 2012). This study was conducted in Rhamu town of Mandera District, North eastern province, in Kenya. Mandera is one of the arid districts of Kenya with an erratic mean annual rainfall of $255 \mathrm{~mm}$, mean temperatures of $28^{\circ} \mathrm{c}$ and a population of 312,000 persons. It borders Ethiopia to the North, Somalia to the East and Wajir District of Kenya to the South. There is a serious trend of events like early marriages that continue to be a matter of concern. The fluctuating numbers in enrolment have triggered interest and thus caused curiosity for investigation in terms of access and retention. This study dealt with the area that is ASAL. Arid and semi-arid areas cover about $80 \%$ of Kenya's land surface and have $25 \%$ of the country's population, which was about 10 million people, (Republic of Kenya, 2003).

Table 1: sample size

\begin{tabular}{|l|l|l|l|}
\hline Respondents & Target Population & Sample Size & \% of Sample size \\
\hline Teachers & 120 & 18 & 15 \\
\hline Students & 800 & 120 & 15 \\
\hline Parents & 360 & 54 & 15 \\
\hline Total & $\mathbf{1 2 8 0}$ & $\mathbf{1 9 2}$ & $\mathbf{1 5 . 0}$ \\
\hline
\end{tabular}

The study used simple random sampling technique to select teachers and parents. Data was collected by use of questionnaires and interview schedule. After writing the questionnaires and before starting the actual data collection, the instruments were pre-tested in two schools in Mandera District. Problems and any unclear questions that arose during the pre-testing were sorted out by reframing the questions.

The instrument was evaluated for content validity. The instrument was scrutinized by my supervisors and lecturers in the department to determine whether the items in the instruments adequately address the objectives of the study. After the pilot study, the questionnaire was tested for reliability using split-half technique. This procedure is preferred because of its ability to measure internal consistency of the instrument being tested.

Data collected was subjected to qualitative and quantitative analysis. Qualitative data comprised answers to open-ended questions in the questionnaires and personal observations. Coding was used to prepare quantitative data for analysis. Quantitative data comprised the close-ended questions and categorized data. Quantitative data was analyzed by coding the data using SPSS (statistical package for social sciences) software and generate descriptive statistics such as percentages, frequency tables and graphs where applicable. This method was chosen because data was categorized according to themes and objectives in relation to the opinion, views and perception of the respondents. Recorded interviews were transcribed; interviews done in mother tongue were translated in English and interpretation done according to emerging patterns from the respondents. 


\section{Results And Discussion \\ Enrollment, Dropout and Performance profile of the Girl -Child}

From study, the finding reveals that the average children per family were 9 with minimum being 4 children and a maximum of 25 children. From this the average ratio of boys to girls who were going to school was $4: 3$, meaning that there was more preference on boys to girls. The researcher established that there was no respondent who admitted knowledge of boys dropping out of school. However, the study shows that there was on average one girl per family dropping out of school. Most of the girls were dropping out of school in between standard five to standard eight as $(70.0 \%)$ of the students interviewed stated that girls who dropped out of school did not voluntarily do so but under different circumstances. It was established that $(72.0 \%)$ of the students and $(91.7 \%)$ of the teachers knew of girls who had dropped out of the school. According to the students, the average number of girls who dropped out of school in form one to form four was two per class with a maximum of up to 18 students.

\section{Factors Responsible for Dismal Enrolment, Retention and Performance}

The students, teachers and parents were asked separately to indicate the factors which they considered to be causing the dismal trends in enrolments, retention, transition and performance of the girl-child in the study locale of Rhamu Town in Mandera County. The results from their responses are summarized in Table 2.

The factor which was ranked highest by a majority of students and parents, comprising $53.3 \%$ and $39.3 \%$ of students and parents, respectively was lack of school fees due to general poverty of parents and community around the study locale of Rhamu Town in Mandera County. This is indeed a major constraining factor since over half of the parents and over one third of the students were in agreement regarding the negative effect of this factor. The finding is in tandem with Orodho (2003. 2014) who pointed out that some retrogressive, socio economic and cultural traditions, religious values and practices have greatly affected access and participation in secondary school education. A study conducted by Saru (2006) revealed similar findings that some of the socio-cultural factors affecting performance in ASAL area including circumcision, early marriages, low opinion of women and a lack of priority in education.

Table 2: Factors responsible for dismal enrolment, retention and performance profile of girls

\begin{tabular}{llll}
\hline Factors causing dismal participation & Students (\%) & Teachers (\%) & Parents (\%) \\
\hline Lack of school fees due to poverty at household & 53.3 & 16.7 & 39.3 \\
Expulsion due to indiscipline in school & 1.3 & - & - \\
Forced Early marriages of girls & 26.7 & 38.9 & 36.9 \\
Teenage Pregnancy & 10.9 & 27.8 & 8.3 \\
Lack of interest and poor participation & 5.3 & 11.1 & 9.5 \\
Other reasons( role models, religious, e.t.c) & 2.7 & 5.5 & 6.0 \\
\hline
\end{tabular}

The second highly ranked factor was forced early marriages of girls by their parents to pre-arranged suitors. This factor was cited by $26.7 \%, 389.9 \%$ and $36.9 \%$ of students, teachers and parents, respectively. The fact that over one third of the total population of teachers and parents were in agreement regarding the negative impact of forced early marriages of girls on education in the study locale underscores the need to urgently address this factor. I fact, nearly 1 student to every five students reached during this study also highlighted the impact of forced early marriages of the girl-child on education in the area. This finding supports Orodhos' (2014) study which established that forced early marriage of the girl -child in most pastoralist communities was a major constraint to the education of the females compared to their male counterparts.

The third highly ranked factor responsible for poor participation of the girl child in education in the study locale was teenage pregnancy. This factor was cited by $10.7 \%, 27.8 \%$ and $8.3 \%$ of the students, teachers and parents, respectively, in the sample. It is evident that this non-school based factor is also equally important factor to consider in education circles. This is more so because majority of the respondents, mainly students and teachers highlighted this factor more than the parent population in the sample. This finding is also in agreement with the observations made by Njeru and Orodho (2003) as well as Orodho (2014) studies that recommended concerted efforts between parents and school administrators in addressing this problem.

The other factors, which were mainly school-based were poor performance and participation in school activities, expulsion due to indiscipline or other related issues such as lack of role models for the girl-child and non-enforcement of the Basic Education Act 2013 clauses that touch on punitive measures to be taken against parents who do not take their children of school going age to school. This finding is in line with that of Ombongi (2008) and Orodho (2014) who similarly found that early marriages influenced participation in education. The studies were in agreement that girls in standard Four or between 12 and 14 years were withdrawn from school to be married off to wealthy men in the community in exchange for dowry. 


\section{Suggested Measures for Addressing the Girl-child Problem}

From the foregoing, it is clear that the girl-child faces numerous challenges in an attempt to access and participate in education in Mandera District. An attempt was made to solicit the opinion and suggestions of the respondent $\mathrm{s}$ on what should be done to overcome the problem of low enrolment of girl-child in schools. The views and opinion were as itemized below:

1. Educating the community on the importance of educating all children irrespective of their gender. In addition, look for mechanism of discouraging early marriages by employing strict measures against any man who marries a girl below the age of 18 years.

2. The government through provincial administration to ensure that all girls who are of school going ages to be in school from tender age. The BoM should interpret the Basic Education Act, especially on the responsibilities of parents and consequences.

3. Motivating top performers by awarding scholarships, employments after o level of education. Sex education and national awareness and increasing political and financial commitment through advocacy and sensitization of policy makers at all levels.

4. The Ministry of Education should intensify the development technical capacity of teachers and schools to create a girl-friendly environment that enables the participation of girls and improve their learning out come.

5. Provide an integrated program which caters both religious and secular needs of the parent of the child in order to change the attitude of the parents. Give incentives to best performing girls in order to encourage and attract more girls to enrol in schools.

From the foregoing suggestions, there is little doubt that the members of the Board of Management as well as community have some good ideas regarding what should be done to enhance the education of the girlchild. These are in line with the expectations of the Basic Education Act 2013 which stresses equal participation in educational provision irrespective of the gender of the learner, geographic location, socioeconomic background and ethnic background (Republic of Kenya, 2013). The constitution of Kenya and the other educational legal documents also stress the need for impartiality and gender equity in access and participation in education( Orodho,2013,2014; Republic of Kenya, 2012a, 2012b).

\section{Conclusion And Recommendations}

The study sought to find out the factors that prohibit the girl- child from transition, performance and retention in secondary schools in arid and semi arid land in the study locale of Rhamu Town, Mandera County, Kenya. From the findings and discussions, the following conclusions can be made:

First, the average ratio of boys to girls who were going to school was 4:3, implying that boys were accessing and participating in school more than their female counterparts. There was no respondent who admitted knowledge of boys dropping out of school. However the study shows that there was on average one girl per family dropped out of school. Most of the girls were dropping out of school in between standard five to standard eight.

Secondly, there were myriad and intertwined challenges facing the education of the girl-child. Early marriages of the girls was critical since girls in primary schools at standard Four and above, typically between the ages of 12 and 14 years were withdrawn from school to be married off to wealthy men in the community in exchange for dowry. In addition, the girls who remained in school were under constant pressure from their peers and community members including their own parents to drop out of school.

Thirdly, although the parents and the community do not attaché high premium to the education of the girl-child, the girls themselves seemed to value education but their dreams are thwarted by some retrogressive socio-cultural practices. As result, fellow students, particularly girls themselves, felt culturally out of place as they don't want to compete with boys especially in a mixed school. This implies that students view girl-child education more positively than both parents and teachers. There is potential to put in place strategies that can reverse the quagmire confronting the girl-child.

Finally, it was apparent that lack of motivation and role models from successful girls that have completed schooling at higher levels was a another contributing factor, since there are few highly educated in the study locale. In addition, the few who stayed in school experienced shortage of female teachers. Most teachers hardly portrayed good standards since female teachers were notoriously absent from school, hence acting as a demotivating factor. 
From the foregoing, the following eight recommendations were made:

1. The government through the Ministry of Education should continue to develop and implement policies to ensure that girls who drop out of secondary school due to pregnancy enroll back to school. The schools should create an enabling environment for girls to enhance retention and smooth transition.

2. The school management should enhance guidance and counseling in schools so as to address the challenges facing the female students like relationships, peer influence, drugs and substance abuse. This will enhance retention of the female students.

3. The parents and the community should be sensitized on the importance of girl child education. The parents should be enlightened on the importance of giving proper parental guidance to their girls and to be more involved in the education of their girls.

4. To create more time for the girls while at home for their studies, the parents need to be sensitized on the importance of proper monitoring of the girls and assign them less domestic chores.

5. The Ministry of Education should provide capacity building for head teachers and teachers in areas like guidance and counseling and efficiency management of schools particularly day schools.

6. Ministry of Education, other stakeholders and education partners should provide and allocate more bursaries for girls and streamline the procedures followed in allocating those bursaries.

7. The Ministry of Education should enhance monitoring of schools and implement affirmative strategies which would benefit the girl child education. This would ensure a smooth transition and retention of girls in secondary school.

8. The BoM and PTA should ensure that schools set realistic and achievable academic pass marks for students in their respective schools. The Board should fully implement the Basic Education Act 2013 and eliminate the issue of forced repetition. It is strongly argued that elimination of forced repetition, along with other constraints discussed above will surely enhance access, retention, and smooth transition of the girl child from one level of education to the other.

\section{Reference}

[1]. Brook,.S.E .(2013).Sampling Issues in qualitative research. Research Methods in education. Aryl Publishers.

[2]. Chimombo, J. (2009). Changing Patterns of access to Basic Education in Malawi: Comparative Education. 297-31. Brook,. S.E .(2013).Sampling Issues in qualitative research. Research Methods in education. Aryl Publishers

[3]. Eshiwani, G.S. (1993). Education in Kenya since Independence. Nairobi: East Africa Educational Publishers Limited.

[4]. Juma, M.N. (1994) Determinants of Female Participation in primary Education: A study of Kwale and Taita- Taveta districts. Nairobi: Kenyatta University. Unpublished PHD Thesis.

[5]. Knight, J.B. \& Sabot,R.H.(1990). Education, Productivity and Inequality. The East African Natural Experiment. New York: Oxford University Press.

[6]. Lockheed, M.E. \&Verspoor, A.M. (1991) Improving Primary Education in Developing Countries. New York: Oxford University Press.

[7]. Mensch, B. S \&Lloyd, C.B. (1998). Gender Difference in Schooling Experience of Adolescent in low Income Countries: The case of Kenya. Studies in Family planning.

[8]. Mwaniki, J.M \& Orodho, A.J.(2014).Dismal performance of boys in Kenya Certificate of Secondary education :Diagnosis of effects of socio-economic factors in Subukia District, Nakuru County, Kenya. International Journal of Current Research, Vol.06, Issue 05,pp. 6919-6926.http://www.journalcra.com

[9]. Njeru, E.H. \& Orodho, J.A (2003) Access and Participation in Secondary School Education in $\quad$

[10]. Noor, A. (2003). Access and retention of Girls in Primary Education, Wajir District, North- Eastern Province of Kenya. Nairobi: Kenyatta University Unpublished Med. Thesis.

[11]. Ombongi, G.(2008). Cultural and Socio-Economic factors influencing Implementation of Free Primary Education in Isiolo District. Nairobi: Kenyatta University. Unpublished Thesis.

[12]. Orodho, J.A. (2009). Elements of Educational and Social Sciences Research Method. Nairobi: Kanezja Publishers.

[13]. Orodho, J.A. (2012). Techniques of Writing Research Proposals and Reports in Education and Social Sciences . Nairobi: Kanezja Publishers.

[14]. Orodho, A.J.(2014).Attainment of education for all (EFA) by 2015: From rhetoric chimera to practice in Kenya. International Journal of Current Research. Vol. 6. Issue 01, pp4666-4674. January 2014. www.journalcra.com .

[15]. Orodho, J.A., Waweru, P.N., Ndichu, M., \& Nthinguri, R .(2013). Basic education in Kenya: Focus on strategies applied to cope with school-based challenges inhibiting effective implementation of curriculum. International Journal of Education and Research (IJER).www.ijern.com .

[16]. Orodho,A.J, Waweru, P.N. \& Getange, K,N.(2014).Progress towards attainment of education for all (EFA) among nomadic pastoralists : How do we dismantle the gender differential jinx in Mandera County, Kenya?.International Organization of Scientific Research (IOSR), Journal of Humanities and Social Sciences (IOSR-JHSS). www.iosrjournals.org .

[17]. Republic of Kenya (1976). Report of the National Committee on Educational Objectives and Policies. Nairobi: Government Printer

[18]. Republic of Kenya (1964). Report of the Kenya Education Commission. Nairobi: English Press Limited. Republic of Kenya. (1996). Report on Audit and General Inspection of National Secondary Schools. Ministry of Education Nairobi: Government Printers .

[19]. Republic of Kenya (1976).Economic Survey. Nairobi: Government Printers

[20]. Republic of Kenya. (1999). Totally Integrated Quality Education and Training (TIQUET). Nairobi: Government Printer.

[21]. Republic of Kenya (2002). National Development Plan. Nairobi: Government Printers.

[22]. Republic of Kenya (2003). National Policy for the Sustainable Development of Arid and Semi-Arid Lands of Kenya. Nairobi: Office of the President.

[23]. Republic of Kenya. (2004) Education Statistical Booklet 1999-2004. Ministry of Education. Nairobi: Government Printers

[24]. Republic of Kenya .(1964). The Ominde Education Report, Nairobi Government Press Ltd. 
[25]. Republic of Kenya. (2005a).) Sessional Paper No. 1 on Policy Reforms for Education, Training and Research: Meeting the Challenges of Education Training and Research in the $21^{\text {st }}$ Century. Ministry of Education, Science and Technology (MOEST Nairobi: MOEST.

[26]. Republic of Kenya(2005b). Kenya Education Sector Support Programme 2005 - 2010: Delivering Quality Education and Training to All Kenyans. Nairobi: MOEST.

[27]. Republic of Kenya.(2012a).Sessional Paper No.14 of 2012 on realigning education and training to the Constitution of Kenya 2010 and Vision 2030 and beyond. Ministry of Education Science and Technology. Nairobi. Kenya.

[28]. Republic of Kenya.(2012b).A Policy Framework for re-aligning education to the Constitution 2010 and Vision 2030 and beyond.

[29]. Republic of Kenya.(2013). The Basic Education Act, 2013 No 14 of 203.The Government Press, Nairobi.

[30]. Republic of Kenya/UNICEF( 2012).Education for All (EFA) End of Decade Assessment (2001 -2010). Ministry Of Education and INICEF. Nairobi.

[31]. Rolleston, C. (2009). The determination of Exclusion: Evidence from Ghana living Standard Survey.

[32]. UNESCO (2008). The Road to 2015: Reaching the Education Goal: Annual Report 2008. Paris: UNESCO.

[33]. UNICEF (2001). We the Children: End Decade review of the Follow-up to the World Summit for Children. New York: UNICEF.

[34]. UNESCO (2009). EFA Global Monitoring Report, Overcoming Inequality: Why Governance matter. Paris: UNESCO

[35]. UNICEF. (1992). Situation analysis of children and women in Kenya 